\title{
Disorders of the cMyb proto-oncogene expression and its significance in the course of ATL development
}

\author{
Kazumi Nakano ${ }^{1 *}$, Atae Utsunomiya ${ }^{2}$, Kazunari Yamaguchi ${ }^{3}$, Kaoru Uchimaru $^{4}$, Toshiki Watanabe ${ }^{1}$ \\ From 16th International Conference on Human Retroviruses: HTLV and Related Viruses \\ Montreal, Canada. 26-30 June 2013
}

Accumulation of genetic disorders in HTLV-1 infected cells underlies ATL leukemogenesis, yet the actual genetic events responsible for cellular transformation have not been fully elucidated. Based on gene expression profiling in 52 ATL patients, 40 HTLV-1 carriers, and 21 healthy volunteers, we determined several potential risk-indicator genes of ATL, including cMyb. cMyb is the proto-oncogene of vMyb, the oncoprotein of avian myeloblastosis virus, governing hematopoietic cell differentiation. Required for differentiation of DN3, survival of DP, and generation of $\mathrm{CD} 4^{+}$-SP cells, cMyb is not expressed at a detectable level in mature T-cells. Among well-known 7 isoforms, cMyb9A and $-10 \mathrm{~A}$, lacking the cis-acting negative regulatory domain (NRD) same as vMyb oncoprotein, are known to be molecules of "gain of oncogenic function". We demonstrated that the mRNA levels of $c m y b-9 a$ and $-10 a$ were drastically elevated in ATL cells. Moreover, cMyb-9A protein was overexpressed in PBMC of HTLV-1 carriers and ATL patients. cMyb-9A showed the highest transactivation of HTLV-1 LTR, which is one of the cMyb targets, among 7 isoforms. The level of cMyb is known to be regulated by SUMOylation through the NRD. As expected, SUMOylation assay showed that cMyb-9A was not effectively SUMOylated, and its activity was not suppressed. Finally, cMyb-9A exhibited a significantly higher transforming activity than WT-cMyb. Upon confirming that cMyb-9A is released from the negative-regulatory circuit of cMyb, we speculate that overexpression of cMyb-9A in HTLV-1 infected cells has a strong link to disorders in cellular homeostasis by overruling its target gene expression, thus accelerating transformation process to ATL.

Graduate School of Frontier Sciences, The University of Tokyo, Tokyo, Japan Full list of author information is available at the end of the article

\section{Authors' details}

'Graduate School of Frontier Sciences, The University of Tokyo, Tokyo, Japan. ${ }^{2}$ Department of Hematology, Imamura Hospital Bun-in, Kagoshima, Japan. ${ }^{3}$ Department of Safety Research on Blood and Biologics, National Institute of Infectious Diseases, Tokyo, Japan. ${ }^{4}$ Department of Hematology and Oncology, Research Hospital, Institute of Medical Science, The University of Tokyo, Tokyo, Japan.

Published: 7 January 2014

doi:10.1186/1742-4690-11-S1-P94

Cite this article as: Nakano et al:: Disorders of the cMyb proto-oncogene expression and its significance in the course of ATL development. Retrovirology 2014 11(Suppl 1):P94.
Submit your next manuscript to BioMed Central and take full advantage of:

- Convenient online submission

- Thorough peer review

- No space constraints or color figure charges

- Immediate publication on acceptance

- Inclusion in PubMed, CAS, Scopus and Google Scholar

- Research which is freely available for redistribution
() Biomed Central 